\title{
Primary Determinant in Quality Deterioration of Fish Seed in Captivity
}

\author{
NR Chattopadhyay ${ }^{1 *}$ and PP Ghorai ${ }^{2}$ \\ ${ }^{1}$ Department of Biotechnology and Zoology, Rajib Gandhi University, Arunachal Pradesh, India
}

${ }^{2}$ Department of Zoology, Vidyasagar University, India

Received: 㘹 June 14, 2018; Published: 眥 June 25, 2018

*Corresponding author: NR Chattopadhyay, Department of Biotechnology and Zoology, Rajib Gandhi University, Arunachal Pradesh, India

\section{Abstract}

This study was primarily undertaken to review the current status of fish seed production at freshwater sector of West Bengal, Bihar and Assam - three leading seed producing states of India (Figure 1) and its distribution range within the state and throughout the country. Main emphasis of the work was to assess how far the current practices are following the principle objectives of the technology i.e. production and supply of quality seed out of captive breeding. With the immediate standardization of the technology, West Bengal farmers adopted the technology of their own (in 98\% cases) and started practicing the technology, initially through hapa breeding and afterwards through the establishment of Chinese hatchery. The realization of huge profit margin within a short period (4-6 months), attracted people from diverse sectors and soon mushroom hatcheries came, who started practicing seed production by learning the mechanical aspects of the technology from neighboring farmers.

The profit-making proposition attracted farmers from Assam and Bihar, who by learning the mechanical aspects of the technology from ignorant fish breeders of Bengal, started seed production in captivity by hiring skilled laborer from Bengal, which continues still today. Even today the entire hatchery operation in Bihar and part of the hatchery operations in Assam is under the control of hired people from Bengal. Misappropriation and profit-making proposition [1] of the technology and subsequent deterioration of quality starts from this point. In the subsequent years, the fish breeders, not being apprised of their faulty breeding practices due to want of any primary training on their part, used the technology only for profit. In the compromization with quantity, quality lost its fragrance and as a consequence a worthy technology became a curse in disguise for the sector.

Within very short period of introduction of technology, the ignorant farmers started practicing improper breeding practices like mixed spawning, use of small number of under aged and undersized breeding population and indiscriminate hybridization for their profit and convenience. Mixed spawning leads to hybridization inadvertently and ultimately affect the native gene pool. Maintenance of small number of founder population leads to inbreeding and the obvious genetic consequences are the increased fry deformities (37.6\%), decreased food conversion efficiency (15.6\%) and fry survival (19\%). Again, the undesirable hybrids [2,3] when find their way into natural system results in "genetic intermixing" and affects the genetic biodiversity of the native fish fauna of Bengal. Along with these the fish breeders are introducing alien fishes almost every year without maintaining any code of practice. This alien introduction and repeated use of unauthorized drugs and feeds (composition totally unknown) severely affecting the native biodiversity and unless checked early it may lead to the extinction of some of the prized fishes of Bengal.

Keywords: Seed quality; Misappropriation; Mixed spawning; Genetic intermixing

\section{Introduction}

Indian carps are seasonal breeders and gonadal recrudescence in these fishes occurs after vernal equinox i.e. on $22^{\text {nd }}$ March prior to breeding seasons [4]. These fishes develop eggs but cannot shed them in captivity. To overcome the demerits of natural collection of spawn, the techniques of induced breeding otherwise known 
as hypophysation was developed in experimental condition. The technique later transferred to field condition, which revolutionized the fish seed production and trade in Bengal in particular. It is observed that Bengal fish seed producer's/hatchery owners, being illiterate and totally unaware of the scientific basis of the technology; inadvertently use the technology only for profit making purpose. In most cases the farmers learn the technology from the neighboring farmers and there was complete absence of any institutional transfer or training program and follow-up action. The Bengal farmers adopted the technology very well and shouldered the responsibility to produce more than $70 \%$ fish seed requirement of the country. At the same time, the farmers modified and refined the technology time to time with their innovative approach From Bengal the technology was transferred to Assam first and then to Bihar, while farmers of both the states visited Bengal hatcheries, may be at the end of seventies. The farmers of both the learn the technology from the ignorant and illiterate fish breeders of Bengal and for establishing hatcheries in their individual states hired skilled labors from Bengal. This indicates that initial establishment and implementation of such a novel technology were done without any scientific approach of program.

Now, with the standardization of the technology and entry of more and more entrepreneurs and business sector, a competitive approach developed among the fish seed producers. This led the farmers to adopt some unfair means and use the technology for profit making purpose. This includes mixed spawning, indiscriminate hybridization (and introduction alien species from neighboring countries. Added to this the farmers out of ignorance never considered potency of the gland and started using immature fishes due to scarcity of brooders during breeding seasons. All these phenomena resulted in serious genetic consequences like inbreeding, genetic introgression etc. The obvious consequences are the negative impact on stock integrity and genetic biodiversity of the native fish fauna. Target oriented research program with strict imposition of laws need to be initiated to check the further loss in biodiversity and maintaining sustainability.

\section{Materials and Method}

The study conducted involving the leading hatchery owners in some of the major seed producing districts of West Bengal, Assam and Bihar. A questioner schedule was prepared and detailed field information was accounted based on the schedule. Fish breeders were interrogated and detailed information were documented regarding the present mode of the application of the technology. The data were compiled and presented in the text. The photographs presented in the text were taken during the field study. Initial study started with West Bengal as it was the pioneer state in implementing the technology, the technology for quality seed production in captivity. Then we proceed to Assam and Bihar as because after standardization of the technology in West Bengal it was transferred to the said two states from West Bengal hatcheries.
In case of Assam, the farmers turned fish breeders learn the technology from the ignorant and illiterate fish breeders, after visiting West Bengal hatcheries during late seventies or early eighties. The scenario of implementation of technology in Bihar is somewhat different. It was envisaged during visit that the entire hatchery operation is controlled by some ignorant hired fish breeders of Bengal, locally known as fish doctor. Even the doctors carry entire batch of pituitary gland with them from West Bengal. The entire operational procedure of implementation of the technology in captivity itself indicate how such a novel technology lost its significance within a period of 30 years and went away far away from its original goal to produce quality seed in captivity. Out of field study 25 hatcheries from each state were selected for and the operational procedure was incorporated in the present paper.

\section{Results and Discussion}

The quality deterioration of seed, through the implementation of induced breeding technology, started with the following misappropriation.

\section{Dissemination of Technology}

The quality deterioration starts with the faulty implementation of the technology, after its discovery at the CIFA centre of Indian council of Agriculture Research, Orissa, India. The transfer of technology, if we count the codes of transfer of technology, developed in the scientific laboratory, here induced breeding technology, didn't follow the code of practice of transfer. Here, we may consider it as an adoption instead of transfer as because the pioneer fish farmers turned fish breeders adopted the technology of their own from neighbouring 1 or 2 hatchery owners, who learned only the manual aspects of the technology from Govt. Official. Very soon Mushroom hatcheries has come up in and around two districts of West Bengal, India, and in most cases the fish farmers learned only the manual aspects of the technology as there was, practically, no initiation from the Govt. Sector and/or Institutional level to appraise the fish breeders about scientific basis of the technology at any level. Quality deterioration starts with the very first step of unscientific dissemination and as the short-term profitmaking quality is appraised, more and more people opted for captive breeding program by learning only the manual aspects of the technology.

\section{Improper Potency of Pituitary Gland}

At the initial stage, before the discovery of synthetic inducing agents like Ova prim, Ova tide, Wova FH etc., pituitary gland was the sole inducing agent. Following the principle of induced breeding, for initiating complete spawning, a pituitary gland should have the right potency. As indicated a rightly potent gland would be that one which is collected from the properly matured fresh fish i.e. fish should be in the 2+ age group and freshly collected. Initial dependence on pituitary led to the development of a chain comprising of gland collector, retailer and supply chain. Collectors 
are hired persons by the retailers and collects gland from the beheaded head parts of the ice preserved fish from the market. The second phase of the quality deterioration occurs with the collection of impotent pituitary gland about which all involved, from gland collector to fish breeders are not concerned out of ignorance and illiteracy. Final impact is the reduction in population size with consequential genetic phenomenon like inbreeding, genetic drift etc.

\section{Brood stock - its Availability and Management}

In a breeding program, the primary input is the readily available male and female fish at the peak of their maturity stage. Along with maturity age and size of the brood fish is also an important consideration for the successful spawning. According to the principle of induced breeding a brood fish in the age and size group of 2-5 is suitable. Collection of brood stock in adequate number from different geographical territories, cataloguing of their geographical origin, their genetic characterization and maintaining their pedigree record are important pre - requisites for breeding program. These aspects are of much genetic relevance for a scientific breeding aiming at quality seed production. Further proper feeding of brood stock and their health maintenance are some important management aspects. Different fish show considerable variations in the number of eggs develop i.e. Fecundity varies. As fecundity refers to number of eggs $/ \mathrm{kg}$ of body weight so it is easy to assess the requirement of brood stock for production of specific number of eggs. The dietary intake of blood stock found to have profound influence on maturation and fecundity of fishes. Experimental results indicate decreased egg production $(75 \%)$ when ration size reduced to half, again decreased ration size during second half of reproductive cycle decrease egg size (Table 1 ).

\section{Species and Stocking Density}

The hatcheries in all the study area, maintain a multi species brood stock pond comprising of IMC, Minor carps, and Exotic carps of different age groups and sizes in very high stocking density. Though multi species carp culture is a recommended practice, but the unscientific manner in which it is carried out is the real cause of concern. It was observed that $80 \%$ of the total seed producers maintained more than six species brood stock ponds with no control over the species ratio and composition (Table 2). It was observed that the species composition included even the banned fish species in the hatcheries.

Stocking density is considered to be one of the vital criteria to be taken into account in brood stock management programme. Most of the hatcheries seem to maintain a very high stocking density in brood stock pond and it was observed that almost all the hatchery owners $(72 \%)$ maintained a stocking density of more than 1500 $\mathrm{kg}$ per hectare. The average stocking density maintained by the hatchery owners was $2315.79 \mathrm{~kg}$ per hectare (Table 1).

Table 1: Brood stock management practice in the area of study.

\begin{tabular}{|c|c|c|c|c|}
\hline \multicolumn{2}{|c|}{ Actors involved in fish seed production } & \multicolumn{3}{|c|}{ Hatchery owners and fish seed producers } \\
\hline \multicolumn{5}{|c|}{ Hatcheries $(n)=75$} \\
\hline \multirow[t]{8}{*}{ Factors } & Indicators & Variables & No of respondents & Percentage \\
\hline & Species & Multi species* & 60 & $80 \%$ \\
\hline & Stocking density & $2315.79 \mathrm{~kg} * *$ & $36^{* * *}$ & $72 \%$ \\
\hline & Feed and fertilizer & Monthly & 60 & $80 \%$ \\
\hline & Infrastructure & Insufficient & 61 & $84 \%$ \\
\hline & Source of brood fish & Own/others & 36 & $72 \%$ \\
\hline & Culling & $\begin{array}{c}\text { Deformed/diseased/ } \\
\text { overage/etc }\end{array}$ & 66 & $88 \%$ \\
\hline & Pedigree & - & 60 & $80 \%$ \\
\hline
\end{tabular}

${ }^{*}(>6$ species $) ;{ }^{*}$ Average; *** $(>1500) \mathrm{kg}$.

\section{Infrastructure for Brood Stock Raising}

The available brood stock raising area, nursery, spawning pool, hatching pool, brood stock biomass etc. available in the hatcheries of study area was insufficient. Altogether, $84 \%$ of the hatchery owner had insufficient area for growing of brood stock in their farm (Table 1). Formula for calculation of the area required for brood fish pond according to Thomas (2003) is:

$\mathrm{ABRP}=\mathrm{BR} \times 1 / \mathrm{SD}$, where

ABRP = Area of brood fish production pond
$\mathrm{BR}=$ Weight of brood fish expressed in $\mathrm{kg}$

$\mathrm{SD}=$ Stocking density of brood fish per ha.

\section{Source and pedigree of brood stock}

The study revealed that $72 \%$ of the hatchery owners do not have sufficient numbers of brooders to sustain the level of spawn production in their hatchery (Table 1). The small farmers depend entirely on outside source for collection of brood fish prior to breeding programme. The big and medium farmers depend both on farm raised and outside source. It was observed that $62 \%$ 
(average) of the total brood fish comes from farmers own pond and the rest 38\% (average) comes from outside source and share basis prevalent among the farmers. The breeders in the hatcheries (80\%), visited during study period, are least bothered to know the pedigree of fish stock they have for the breeding programme to be carried out in their farms (Table 1). None of the farms were found to maintain pedigree record of the brood stock, repeatedly using for seed production since long back, required to avoid the mating of close relatives. Cultured populations should be identified by using a proper marking system. Females \& males should be from two different lines.

\section{Culling}

The practice of eliminating or culling of fish from the breeding programme is the necessity of the modern breeding programme. The culling of fish could be based on the criteria based on the phenotype of fish such as growth, disease, deformity, age, size, and most catchable fish than least catchable during harvesting. No such activity was adopted by any of the fish seed producers of the study area, instead one of the breeder was seen injecting a grass carp fish for induce spawning with a tumour like lump on the skull region of the fish (Figure 1). According to the information provided by him, it was learnt that he has been breeding the same fish for the last couple of years. Table1 conforms that majority of the breeders have no idea about the importance of culling of fish from the breeding programme. Quality deterioration finds its easy routes when a diseased fish used as brooders.

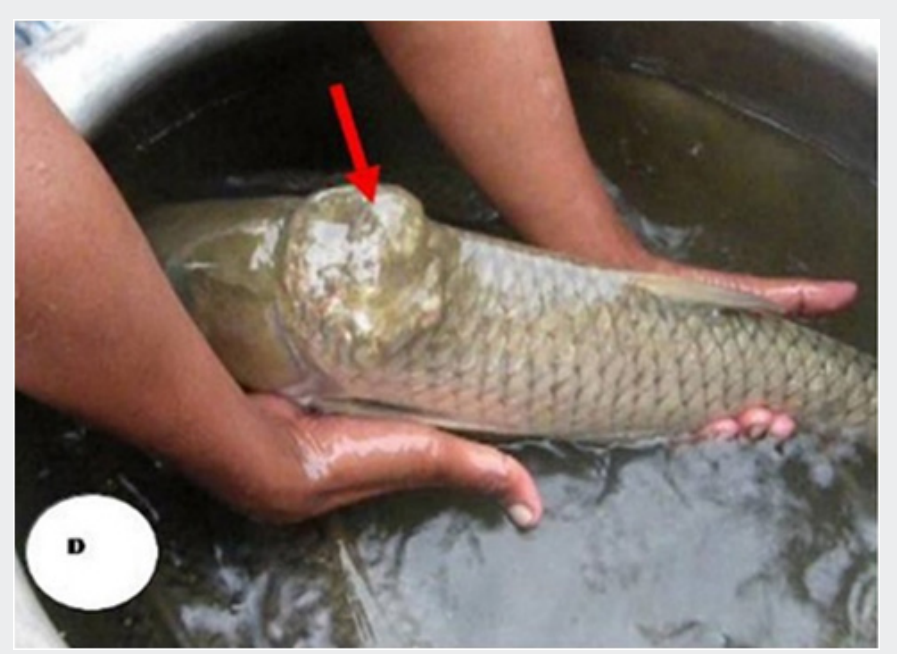

Figure 1: Tumour like lump on upper Cephalo -thoracic region, a potent candidate as brood fish.

\section{Feed and fertilizer}

Majority of the hatchery managers do not have proper feeding schedule for the brood stock or nursery management and provide (80\%) feed and fertilizer on monthly basis (Table 1). It is just before the start of the breeding season there is a change in feeding schedule. From February onwards, protein rich feed composed of cereals, broken rice, fish meal etc., after boiling in large pot (karai) are broadcasted in the pond arbitrarily two times a day, without any consideration to the bodyweight. In West Bengal and
Bihar, the farmers and fish breeders are more interested in using floating feeds, the reason, as they advocated that as the feeds are floating so it helps them to gaze the amount of feed required by the total biomass, besides it creates no pollution. Whatever it may be the entire supply chain of all the aquaculture products like feed, medicine, chemicals, probiotics and inducing agents are under the control of some unscrupulous middleman/agents. Many a times these products fail to fulfil the criteria of the specific needs for which they are used. The consequences are that the users are deprived of getting the expected results.

Table 2: Breeding Practices as adopted by the Fish breeders of Three States.

\begin{tabular}{|c|c|c|c|c|}
\hline \multicolumn{2}{|c|}{ Actors involved in fish seed production } & \multicolumn{3}{|c|}{ Hatchery owners and fish seed producers } \\
\hline \multicolumn{5}{|c|}{ Hatcheries (n) = 75} \\
\hline \multirow[t]{6}{*}{ Factors } & \multicolumn{2}{|c|}{ Indicators } & No of respondents & Percentage \\
\hline & \multicolumn{2}{|c|}{ Natural breeding } & 36 & $32 \%$ \\
\hline & \multicolumn{2}{|c|}{ Stripping } & & $78 \%$ \\
\hline & \multicolumn{2}{|c|}{ Restocking } & 57 & $76 \%$ \\
\hline & \multirow{2}{*}{ Inducing agent } & $\mathrm{CPE}$ & 36 & $48 \%$ \\
\hline & & OVAPRIM & 60 & $80 \%$ \\
\hline
\end{tabular}




\section{Faulty breeding practice}

\section{Need of the farmers}

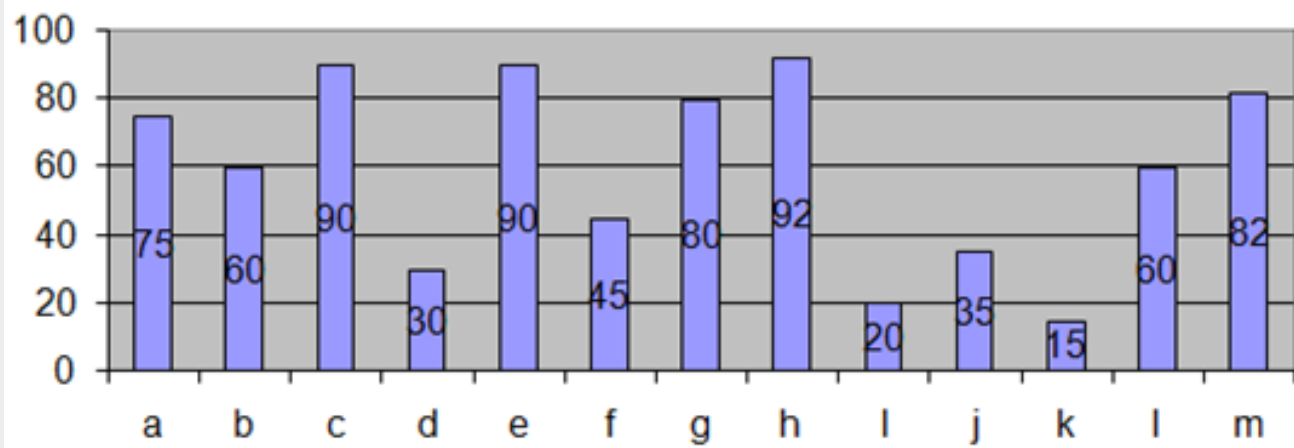

Figure 2: Need of the farmers as quantified (\%) from the survey. (a=specialized training, $b=$ Institutional Finance, $c=$ soil and water testing $\mathrm{d}=$ =institutional coverage, $\mathrm{e}=$ organized fish seed market, $\mathrm{f}=$ unhealthy competition, $\mathrm{g}=$ exemption of taxation during transportation, $\mathrm{h}=$ introduction of new species, $\mathrm{i}=$ change in land revenue act, $\mathrm{j}=$ supply of quality food, $\mathrm{k}=\mathrm{removal}$ of discrepancy in breeding program, $\mathrm{l}=$ supply of quality brooders $\mathrm{m}=$ specific aquaculture medicine).

As indicated, the actors involved in operating the captive breeding program are totally ignorant about scientific basis of the technology and they are using the technology only for profit making proposition. Mixed spawning, multiple breeding (Figure 2 ) is the normal practice due to convenience and profit. Mixed spawning (more than $80 \%$ ), is mainly undertaken to cut the water and electricity budget, as because in case of single species breeding, separate breeding pool is required. Mixed spawning leads to indiscriminate hybridization resulting in genetic introgression and other related consequences [5].

In Bihar the entire hatchery operations are under the control of some hired skilled labourer, but in Assam the operations are partly under the control of some hired skill labourer from Bengal. Not being appraised of the basic principles of the technology and to meet the demand of the customers as also to fulfil the profit of the hatchery owners, they adopt all sorts of misappropriation, starting from the use of impotent gland to mixed spawning, hybridization, multiple breeding, use of under aged diseased fishes as brood fishes. Cross verification of some of the leading hatchery owners of three states emphatically said that in more than $80 \%$ cases the fish breeders adopt all sorts of misappropriation to achieve their target.

\section{Problems \& Suggestions from Farmers}
a) Inadequate technical know how
b) Finance
c) Poaching, poisoning of water body
d) Labor dispute, flooding and water logging of the farm sit
e) Availability of quality pituitary gland
f) Excavation of pond in agriculture land

g) Selling of fish seed on $3^{\text {rd }}$ and $4^{\text {th }}$ day of incubation.

8. Suggestions from the Fish Breeders/Farmers

a) Institutional Training Program

b) Changes in Land Revenue Act.

c) Easy Finance.

d) State wise Hatchery establishment for reducing mortality during transportation.

e) Standardization in breeding should be stopped.

f) Dishonesty in breeding should be stopped.

g) Some progressive farmer suggested that household waste water should be drained to a common place on a cluster basis and may be used for backyard fish farming so that some kind of social fishery might be developed. The farmer also suggested that suitable drainage plan should be incorporated during the plan making of house building.

h) Poaching should be stopped.

i) Management of water quality.

j) Subsidy in electricity.

\section{Conclusion}

Thestudy indicates that how proper and scientific dissemination of a technology is important for sustenance of the technology. Here, illiteracy, ignorancy on the part of fish breeders about the scientific basis of the technology plays a negative role against its proper implementation. This is the $1^{\text {st }}$ phase of the beginning of quality deterioration of fish seed in captivity. The initial phase starts with use of impotent gland in most of the breeding program. With the 
increasing demand for quality carp seed from captivity, the demand for pituitary glands were becoming more ex-pensive and their availability is decreasing. Often, batches of these pituitaries are bad as they are collected from the market where dead fishes are preserved under ice. Decrease in their potency is leading to failure in spawning. To overcome these problems, induced spawning of carps and other important fishes, in many countries, are now carried out with GnRH or its analogue [6] which release endogenous GTH and effects spawning in a much confident manner than the crude pituitary extract.

Besides, Pituitary extract very often also contains pathogenic micro-organisms causing infection in fishes. Moreover, pituitary GTH is glycoprotein in nature and is extremely sensitive to temperature denaturation. Hence, GnRH is no doubt a better alternative for induced spawning. But there is one problem with GnRH use; its activity is inhibited by endogenous dopamine. Dopamine occupies GnRH-receptor and thus blocked its action on pituitary gonadotroph cells. Use of domperidone (or pimozide), a dopamine antagonist, increases GnRH-receptor capacity, thus enhancing GnRH responsiveness [7]. Therefore, for induced ovulation, together with salmon GnRH-analogue, pimozide (antidopamine) has been use. On the basis of information, Ova prim, a commercial product has been prepared by the Syndel Laboratories, Canada, which is now marketed by Glaxo Laboratories Ltd for induced breeding of fish.

Though Assam breeders exclusively use synthetic hormones, the West Bengal and Bihar breeders still use the pituitary extract as the primary inducing agent. They claim that pituitary is more

Table 3: Faulty Approaches in Breeding practice \& related criteria.

\begin{tabular}{|l|c|c|c|c|}
\hline \multicolumn{2}{|c|}{ Hatcheries (n) = 75 } \\
\hline \multirow{4}{*}{ Actors involved in fish seed production } & Variables & No of respondents & Percentage \\
\hline \multirow{4}{*}{ Factors } & Indicators & $6.5-8.3 \mathrm{yrs}{ }^{* *}$ & $45 \#$ & $60 \%$ \\
\cline { 2 - 5 } & Breeding Age* & $0.53-5.29 \mathrm{~kg} * *$ & $36 \# \#$ & $48 \%$ \\
\cline { 2 - 5 } & Size & M:F=5:7** & $30 \# \# \#$ \\
\cline { 2 - 5 } & Sex ratio (Skewed) & $2(\mathrm{Gc}, \mathrm{Sc}, \mathrm{Bh})$ & 51 & $70 \%$ \\
\cline { 2 - 5 } & Multiple spawning & $3(\mathrm{IMC}, \mathrm{Mc})$ & & $72 \%$ \\
\hline
\end{tabular}

A further important point is that breeding between two genetically discreet or distant populations may have a positive impact on aquaculture production. As indicated in Table 3 due to dire scarcity of brood fish, except large hatchery owners there was no organized brood stock management practice, the fish breeders adopt all sorts of misappropriation to manage the customers demand. This create some important avenues for quality deterioration of seed in captivity, Mixed spawning, another profit-making approach by the fish breeders, leads to genetic effective in stripping and also put blame about the ineffectiveness of synthetic hormone in many cases. Comparative study on the efficacy of two inducing agent on individual species may help in dissolving confusion. Though brood stock can maintain on maintenance ration but recent information, as revealed by various experimental results, indicate deficiency of certain dietary ingredients such as fatty acids (PUFA), vitamins, trace elements, can have negative impact on maturation, breeding, spawning, larval vigor and survivality. Keeping in mind that nutritional requirement varies according to species, proper experiment should be designed to formulate right food for individual brood stock so that supply of quality seed will be ensured to the farming sector.

Experimental study on wild stocks of $C$. catla represent a diversified genetic resource and indicates that in situ management practices, such as preventing the wanton capture of fish and creating sanctuaries for protecting small stocks such as those in major rivers, can help maintain and conserve the present diverse gene pool. Hatchery owners are accustomed to operating negative selection and polygynous breeding systems in which some males mate with many females year after year, resulting in genetic deterioration that subsequently cause a negative impact on aquaculture production. Based on our present findings, hatchery owners can collect their brood fish or replace their existing breeding populations with genetically diverse fish from stocks like those in the rivers and increase their effective breeding populations and thus improve the aquaculture production. However, the strict implementations of correct management practices are essential to maintaining the genetic diversity of the natural stocks. introgression [8] among the genetically flexible different species of fish [9] while repeated use of small number of founder population for seed production results in inbreeding. All these faulty breeding practices throughout the years has eroded the qualitativeness of the technology, as established by the frequent claim by the seed buyers regarding the poor performance in terms of growth in particular. Other related criteria like use of skewed sex ratio and immature brood fish are also producing negative impact against quality of seed. A consolidated program from Govt. and institute level need 
to be initiated for general appraisal of the misappropriation with implementation of suitable laws banning the faulty practices can provide sustainability to such a novel technology [10].

In all, it can be said that the first criteria to consider the development of aquaculture sector is the steady availability of quality seed locally (within the states and country) to meet the requirements of the industry. Where ever this has not been possible, seeds and /or brood stock may be introduced through certification. It is encouraging to observe that we are in a stage where the emphasis is slowly shifting from quantity to quality. Only in very recent years farmers began to realize the importance of quality seed i.e. pathogen free uniform size seed to remove their sufferings and to maximize production. It may not be entirely wrong to say that this shift in emphasis (attitude) to seed quality has come about largely because of the recurrent disease problems that has besieged the aquaculture industry especially shrimp and fresh water prawn.

\section{References}

1. Padhi BK, Khuda Buksha AR (1989) Natl Acad Sci Lett 12: 59-61.

2. Natarajan AV, Desai VR, Mishra DN (1979) J Inland Fish Soc India 8: 8390.
3. Jhingran VG (1985) Fish and Fisheries of India, Oxford-IBH, New Delhi, India, pp. 727.

4. Sunderaraj, Sudhir Vasal (1976) Photoperiod and Temperature Control in the Regulation of Reproduction in the Female Catfish Heteropneustes fossilis. Journal of the Fisheries Research Board of Canada 33(4): 959973.

5. Kincaid L (1983) Inbreeding in fish populations used in aquaculture. Aquaculture 33(1): 215-227.

6. Siddhartha Halder, S Sen, S Bhattacharya, AK Ray, A Ghosh, et al. (1991) Induced spawning of Indian major carps and maturation of a perch and a catfish by murrel gonadotropin releasing hormone, pimozide and calcium. Aquaculture 97(4): 373-382.

7. Bhattacharya S (1999) Recent advances in the hormonal regulation of gonadal maturation and spawning in fish Current Science 76(3): 342349.

8. Kirpichinikov VS (1981) Genetic Bases of Fish Selection. Berlin, Germany, pp. 410.

9. Eknath AE, Doyle RW (1990) Effective population size and rate of inbreeding in aquaculture of Indian major carps. Aquaculture 85(1-4): 293-305.

10. Sunderaraj, Sudhir Vasal (1976) Photoperiod and Temperature Control in the Regulation of Reproduction in the Female Catfish Heteropneustes fossilis. Journal of the Fisheries Research Board of Canada 33(4): 959973.

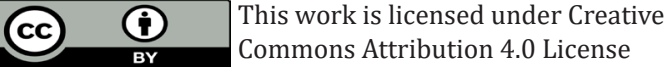

To Submit Your Article Click Here:

Submit Article

DOI: $10.32474 /$ CIACR.2018.03.000160

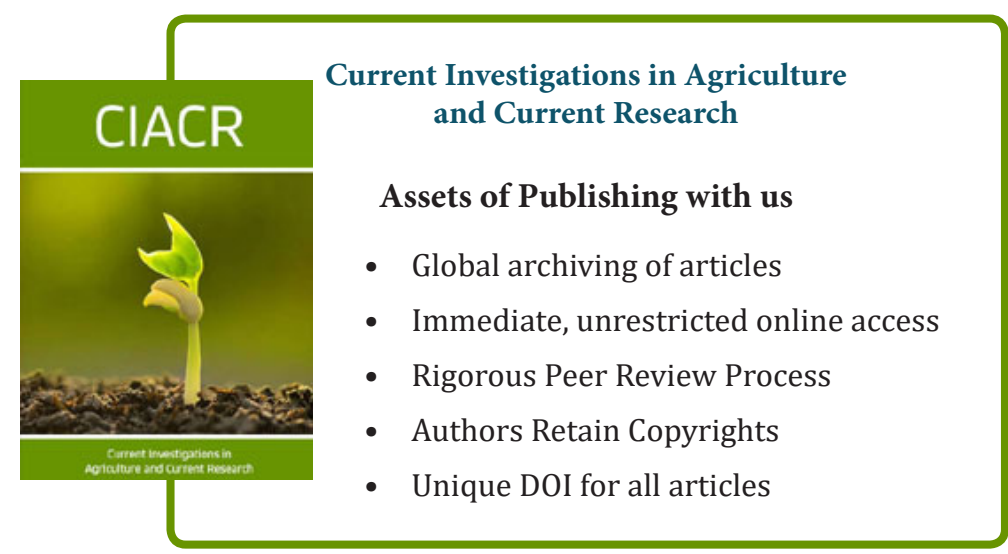

